\title{
Selection of drought-tolerant local rice cultivars from East Nusa Tenggara, Indonesia during vegetative stage
}

\author{
YUSTINA CAROLINA FEBRIANTI SALSINHA ${ }^{1}$, DIDIK INDRADEWA ${ }^{2}$, YEKTI ASIH PURWESTRI ${ }^{1,3}$, \\ DIAH RACHMAWATI ${ }^{1, v}$ \\ ${ }^{1}$ Department of Tropical Biology, Faculty of Biology, Universitas Gadjah Mada. Jl. Teknika Selatan, Sekip Utara, Sleman 55281, Yogyakarta, Indonesia \\ Tel./fax.: +62 274-564305, ^email: drachmawati@ugm.ac.id, yustina.c.f@mail.ugm.ac.id \\ ${ }^{2}$ Department of Agronomy, Faculty of Agriculture, Universitas Gadjah Mada. Jl. Flora, Bulaksumur, Sleman 55281, Yogyakarta, Indonesia \\ ${ }^{3}$ Research Center for Biotechnology, Universitas Gadjah Mada. Jl. Teknika Utara, Barek, Sleman 55281, Yogyakarta, Indonesia
}

Manuscript received: 2 September 2019. Revision accepted: 19 December 2019.

\begin{abstract}
Salsinha Y C F, Indradewa D, Purwestri Y A, Rachmawati D. 2020. Selection of drought-tolerant local rice cultivars from East Nusa Tenggara during vegetative stage. Biodiversitas 21: 170-178. East Nusa Tenggara (NTT), with the predominance of dry climate, has the potential of the plant with high tolerance to drought. This research was conducted to select drought-tolerant rice cultivars. There were eight NTT-rice cultivars tested: Pak morin (P1), Mapan (P2), Pak Mutin (P3), Gogo Fatuhao (P4), Seratus-malam Boawae (P5), Padi-Putih Kuatnana (P6), Padi-Putih Maumere (P7) and Gogo Sikka (P8) with 2 control cultivars tested: Ciherang (drought- susceptible) and IR-64 (drought tolerant). The treatment included were 100\% FC (control), 50\% FC (moderate) and 25\% FC (severe drought) during vegetative stage. The morphological analysis of plant (plant height, number of leaves and tillers and root architecture) showed cultivars P1, P5 and P6 possess the best characteristics for tolerating drought. The physiological analysis (plant photosynthetic rate, stomatal conductance, intercellular $\mathrm{CO}_{2}$-concentration, and transpiration rate) showed cultivar P5 and P6 possess the best characteristics for tolerating drought. The high levels of chlorophyll and carotenoid contents during drought conditions were observed in P5, P6, and P7 cultivars. Based on the relative water content, membrane stability index and proline levels, highest-resistance cultivar was P5 and P7 while the cultivar with high sensitivity to drought stress was P3. Based on the morphophysiological characteristics, it can be concluded that P5, P6, and P7 cultivar have the potential as drought-tolerant rice.
\end{abstract}

Keywords: Drought tolerance, East Nusa Tenggara, field capacity, local rice, morphophysiology

\section{INTRODUCTION}

Climate change has detrimental effects on plants, especially in terms of water supply for their productivity and development (Yang et al. 2016). According to Taiz and Zeiger (2002), water stress conditions are physiological phenomena that cause deviations in the physiological functions and photosynthesis of plants as well as development and growth that has irreversible effects. To increase crop productivity in water stress conditions, it requires efforts to improve plant adaptation to abiotic stress in sub-optimal land (Singh et al. 2017; Mishra et al. 2019).

Based on Meteorological, Climatological, and Geophysical Agencies (BMKG), most of the East Nusa Tenggara (NTT) region is consisted of several islands including Timor, Sumba, Flores, Alor, Rote and several other islands with diverse geographical conditions and dominated by the dry climate. From 2001 to 2010 NTT had a relatively low mean rainfall of $0-12 \mathrm{~mm}$ in the dry month (May-October) and 50-300 $\mathrm{mm}$ in the wet month (November-April) (Hosang et al. 2016).

To increase food production in the NTT region, agricultural business is carried out through the development of drought-tolerant upland rice. East Nusa Tenggara region has many cultivars of local upland rice germplasm of about 21 upland rice lines that are cultivated through traditional techniques. Based on the evaluation of the Indonesian Center for Agricultural Biotechnology and Genetic Resources (BB-Biogen) Bogor, it is known that the NTT region has 91 accessions of food plants from 19 districts with 61 accessions of local rice plants spread in 11 districts in NTT (Hosang et al. 2016).

Morphophysiologically, plants in drought conditions have decreased germination index, plant height, and biomass. Meanwhile, physiological and biochemical effects lead to reduced levels of chlorophyll, stomatal conductance, water potential, relative cell water content, and increased ABA levels that lead to reduced activity in photosystems I and II (Pandey and Shukla, 2015). In this condition, there is an increase in electronic leakage (EL) of the cell which shows the damage to cell membranes due to oxidative stress. This is related to water limitations or decreased relative water content in vegetative plants which are exposed to drought (Yang et al. 2016).

Drought-tolerant rice plants are characterized by their ability to carry out adaptation and tolerance strategies in the form of adjustment of water osmotic potential and relative water content (RWC) of leaves, and also morphological and anatomical adaptations in the form of changes in plant organ structure and biochemical adaptation through activation of oxidative defense mechanisms (Swapna and Shylaraj 2017). Chlorophyll and carotenoid levels are also important characters related to the photosynthetic activity (Pandey and Shukla 2015). 
Chlorophyll is related to the conversion of photon energy in light reactions, while carotenoids are associated with cell protection in photosynthetic activity. The higher the level of photosynthetic pigment, the higher the rate of photosynthesis of a plant to a certain extent (Taiz and Zeiger 2002).

Research conducted by Shehab et al. (2010); and Usman et al. (2013); show plant defenses in drought conditions also involve osmotic adjustment through the accumulation of several secondary metabolites, such as proline. Changes in proline levels were also observed in rice exposed to drought conditions (Bunnag and Pongthai 2013; Lum et al. 2014). The increase in proline levels is one of the main tolerance mechanisms associated with osmotic defense in cells. This is supported through data on the drastic reduction in proline levels in recovery conditions (Maisura et al. 2014).

By observing morphological and physiological changes during drought stress associated with the tolerance of NTT local rice plants, the information about the ability of these rice plants in drought conditions can be obtained to select potential local NTT rice that is tolerant to drought.

\section{MATERIALS AND METHODS}

\section{Study area}

The materials were eight (8) NTT local rice samples (Oryza sativa L.) (non-pigmented) collected from five different locations in NTT province, Indonesia and two control rice cultivars in the form of $O$. sativa 'Ciherang' (drought-sensitive rice) and $O$. sativa 'IR-64' ( droughttolerant rice) with characters according to Table 1 and Figure 1.

The study was conducted at the Greenhouse of the Sawitsari Research Station, Faculty of Biology Universitas Gadjah Mada, Indonesia with mean temperature at about $25-29^{\circ} \mathrm{C}$ at the morning and $30-34{ }^{\circ} \mathrm{C}$ in the afternoon, with sun exposure ranged from $\sim 4500$ lux (in the morning) to 53000 lux (during daylight). The selection process was carried out using variations in field capacity treatment $(100 \% \mathrm{FC}$ for control, $50 \% \mathrm{FC}$ for moderate-drought and $25 \% \mathrm{FC}$ for severe-drought) using the Randomized Complete Blocked Design (RCBD) with four blocks representing four replications with each treatment of drought consisted of 40 plant samples.

Twenty-one DAI (day after imbibition) seedlings were transferred into single plastic pot with a composition of soil: fertilizer ratio (3: 1) and were arranged at a spacing of $20 \mathrm{~cm}$ between pots. The arrangement consisted of four blocks with three levels of FC in each block. While each level of FC consisted of 10 cultivars arranged randomly. Weeding was done every 7 days. Drought stress treatment was carried out when the plants reached 7-46 days after planting (DAP). Growth characteristics (plant height, number of leaves and number of tillers) were measured at the age of 7-46 DAP while photosynthetic characteristics analysis was carried out at 28 DAP, chlorophyll and carotenoid levels at $30 \mathrm{DAP}, \mathrm{RWC}$ at $35 \mathrm{DAP}$, membrane stability index $35 \mathrm{DAP}$, and proline levels at $37 \mathrm{DAP}$.

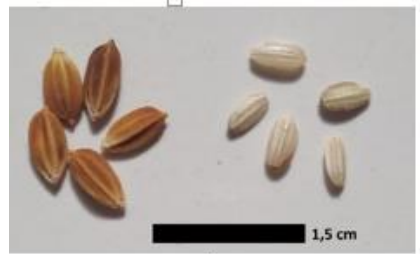

A

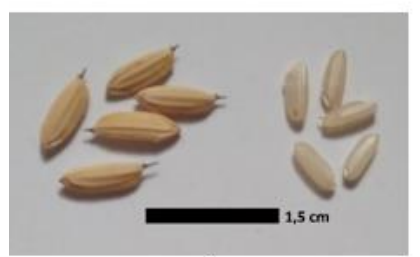

$\mathbf{E}$

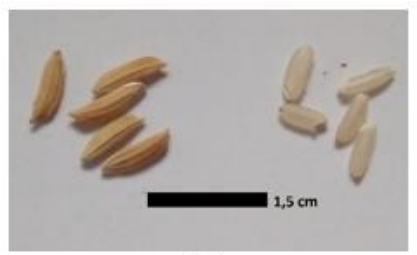

$\mathbf{B}$

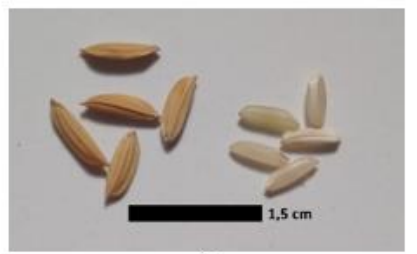

$\mathbf{F}$

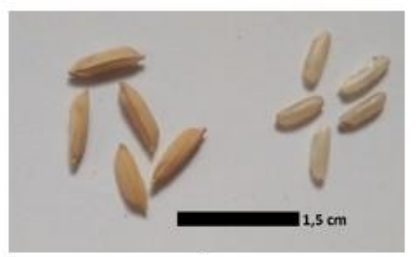

I

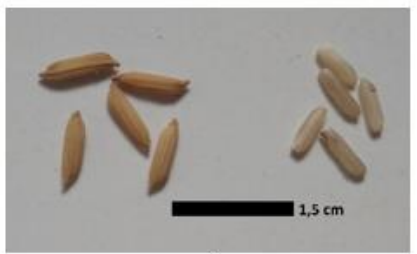

C

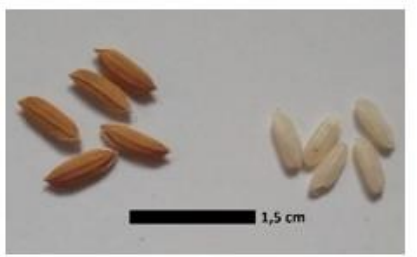

G

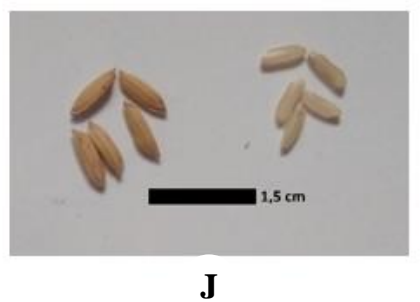

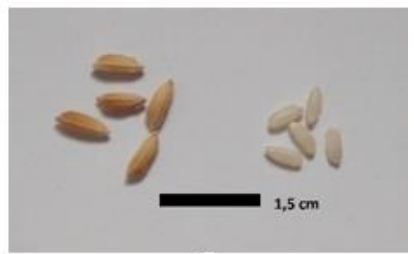

D

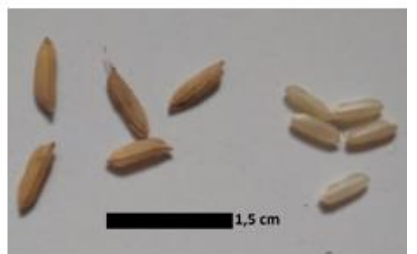

$\mathbf{H}$

Figure 1. NTT local rice seeds: A. Pak Morin, B. Mapan, C. Pak Mutin, D. Gogo Fatuhao, E. Seratus Malam Boawae, F. Padi Putih Kuatnana, G. Padi Putih Maumere, H. Gogo Sikka, I. IR-64, J. Ciherang. Bars $=1.5 \mathrm{~cm}$. 
Table 1. Seed and agronomic characteristics of eight NTT local rice cultivars

\begin{tabular}{|c|c|c|c|c|c|c|}
\hline Abv & Local name & Origin & Seed description & Pericarp color & Hull color & $\begin{array}{l}\text { Days to } \\
\text { maturity }\end{array}$ \\
\hline P1 & Pak Morin & Malaka & $\begin{array}{l}\text { Oval shape, seed diameter is firm, there } \\
\text { are } 6 \text { rib lines on the seed }\end{array}$ & Milky white & Yellowish-brown & 110 days \\
\hline $\mathrm{P} 2$ & Mapan & Malaka & $\begin{array}{l}\text { The shape of the lancet, flat, clear center } \\
\text { line }\end{array}$ & Pale white & $\begin{array}{l}\text { Pale yellow with } \\
\text { brown spots }\end{array}$ & 110 days \\
\hline P3 & Pak Mutin & Malaka & $\begin{array}{l}\text { Oval shape, slightly lanceolate, the } \\
\text { centerline is clearly visible }\end{array}$ & Ivory & Pale yellow & 120 days \\
\hline P4 & Gogo Fatuhao & Kefa & $\begin{array}{l}\text { Oval shape, flat, lanceolate tip, firm } \\
\text { middle rib }\end{array}$ & Milky white & Golden yellow & 130 days \\
\hline P5 & $\begin{array}{l}\text { Seratus- Malam } \\
\text { Boawae }\end{array}$ & Nagekeo & $\begin{array}{l}\text { Long-form, lanceolate, less firm lines, } \\
\text { the tip of the seeds have spina-like } \\
\text { structures (yellow-black) }\end{array}$ & Yellowish white & Bright yellow & 100 days \\
\hline P6 & Padi Putih Kuatnana & Kuatnana & Oval, flat, firm ribs & Milky white & Bright golden & 100 days \\
\hline P7 & Padi Putih Maumere & Maumere & Oval, flat, short, clear ribs & Milky white & Reddish light brown & 90 days \\
\hline P8 & Gogo Sikka & Mumere & $\begin{array}{l}\text { The shape of the lancet, the ribs are not } \\
\text { very clear }\end{array}$ & Brownish white & Pale yellow & 90 days \\
\hline
\end{tabular}

\section{Procedures}

The treatment of variations in the field capacity (FC) level is carried out by first determining the field capacity of the soil: fertilizer ratio 3: 1 for 4 days. Variations in field capacity $(100 \%, 50 \%$, and $25 \%)$ are calculated against the $100 \%$ specified field capacity. Field capacity was quantified using gravimetry method. Each pot was weighed and filled with $4 \mathrm{~kg}$ soil and compost, fulled with excess water inducing drainage and covered with plastic cover. After left for 2 days (until the last gravitational water flowed out/saturated), pot and moist soil were weighed again and dry in an oven at $105^{\circ} \mathrm{C}$ till it was constant. Moisture at field capacity was calculated using formula:

$$
\text { FC }(\%)=\frac{\text { Moist weïght }- \text { Dry weïght }}{\text { Dry weight }} \times 100 \%
$$

\section{Observation of morphological characters:}

Observation of the roots seedling architecture was carried out by the paper-roll germination method. The seeds that have been soaked for 4 hours are placed in a row on porous paper coated with mica, then rolled. The rolls are placed vertically on beaker filled with distilled water and placed in a place exposed to sunlight for 7 days.

Plant height was measured as the distance between the longest leaf tip and the base of the plant above the soil surface. The number of leaves and tillers was counted.

\section{Observation of physiological characters:}

Photosynthesis rate, intracellular $\mathrm{CO}_{2}$ concentration, stomatal conductance, and transpiration rate was observed using Portable Photosynthetic Analyzer (Li-Cor LI6400XT).

\section{Determination of chlorophyll and carotenoid levels:}

According to the method of Harborne (1984) with several modifications, leaf sample of about 0.3 grams was ground with a mortar and homogenized with $3 \mathrm{ml} 80 \%$ cold acetone solution. Chlorophyll levels were determined through spectrophotometer readings (GENESYS $10 \mathrm{UV}$ Scanning, Thermo Scientific) at multi-wavelength of 470, 645 and $664 \mathrm{~nm}$ and expressed in $\mathrm{mg} / \mathrm{g}$ FW (fresh weight).

\section{Determination of proline content:}

Leaf samples of 0.25 grams were ground and homogenized with $5 \mathrm{ml}$ of $3 \%$ sulfosalicylic acid solution (Bates et al. 1973). In a ratio of 1: 1: 1 the sample was mixed with the ninhydrin reagent (containing ninhydrin, acetic acid, and phosphoric acid) and glacial acetic acid and then heated at a temperature of $95^{\circ} \mathrm{C}$ for 60 minutes in a water bath (Memmer GmbH + Co.KG.WNB-7). The solution was cooled to $25^{\circ} \mathrm{C}$ and reacted with toluene to form two layers. Proline levels are determined by comparing the absorbance of the solution at a wavelength of $520 \mathrm{~nm}$ and compared with the standard proline curve.

\section{Relative water content:}

Six leaf pieces $\left(1 \mathrm{~cm}^{2}\right)$ taken from different tillers in each pot and placed into pre-weighed tubes and sealed (Stocker, 1929 cit Mullan and Pietragalla, 2011 with modifications). The tubes and leaves were weighed for its initial weight $(\mathrm{FW})$ then added $1 \mathrm{ml}$ of $\mathrm{ddH}_{2} \mathrm{O}$ until tube height increased by $1 \mathrm{~cm}$, then incubated for 24 hours at room temperature. After that weighing was done to determine the weight of turgid (TW), then dried at $75^{\circ} \mathrm{C}$ for 48 hours and weighed to determine the dry weight (DW), then RWC is calculated based on formulas (Mullan and Petragalla, 2011):

$$
\text { RWC }(\%)=\frac{\text { Fresh weight }- \text { Dry weight }}{\text { Turgid weight }- \text { Dry weight }} \times 100 \%
$$

\section{Cell membrane stability index:}

Cell membrane stability index was determined based on the number of ions contained in $\mathrm{ddH}_{2} \mathrm{O}$ according to Guo et al. (2007) and Singh et al. (2017). Two hundred mg of leaf were cleaned and cut with a length of $5 \mathrm{~mm}$ and put in a tube containing $20 \mathrm{ml} \mathrm{ddH} 2 \mathrm{O}$. The tubes were incubated for 12 hours at room temperature with constant lighting. 
The value of the conductivity of the solution is measured with an Electro-conductivity meter (EC-meter CM-21P, TOA Corp, Japan) as the initial conductivity (EC1), then the solution is boiled to $100^{\circ} \mathrm{C}$ for 15 minutes and cooled to $25^{\circ} \mathrm{C}$ then the EC is measured as EC2 and ISM determined by the following formula:

$$
\operatorname{ISM}(\%)=\left[1-\frac{E C 1}{E C 2}\right] \times 100 \%
$$

\section{Data analysis}

The analysis of homogeneity and normality data were tested using One-Way ANOVA. The significance of the data and interactions of cultivars and Field Capacity treatments on plant height, number of leaves, and number of tillers at the end of the experiment as well as physiological parameters and other biochemical activities were tested with One-Way ANOVA and continued with Duncan test conducted at 95\% confidence level. Correlation analysis was carried out using the PearsonCorrelation Test (significant differences was considered at $\mathrm{P}<0.05$ ) with IBM-SPSS Ver. 20.0 (US).

\section{RESULTS AND DISCUSSION}

\section{The phenotype of growth character}

Phenotype characters like rooting architecture are a character that can be significantly influenced during drought stress. This is related to root growth which is sensitive to the influence of osmotic differences and potential gradient changes in root cell membranes. The structure and development of the rice plant root system have been shown to affect the physiological performance of plants during drought stress (Hsiao and Xu 2000). Research by Singh et al. (2017) shows that root architecture screening in the early growth phase has been used as a method of selecting tolerant cultivars in Sorghum bicolor and Zea mays.

By using the vertical root observation method, it shows the character of the root architecture (Figure 2) before it was exposed to drought conditions. Tolerance to drought is demonstrated through deep root character and high branching ability (Pandey and Shukla 2015). Based on the visualization of rooting conditions at the age of 7 DAI, cultivars with a dense branching system namely Pak Morin, Padi-putih Maumere and Gogo Sikka while cultivars with deep root characters were demonstrated by Pak Mutin cultivars.

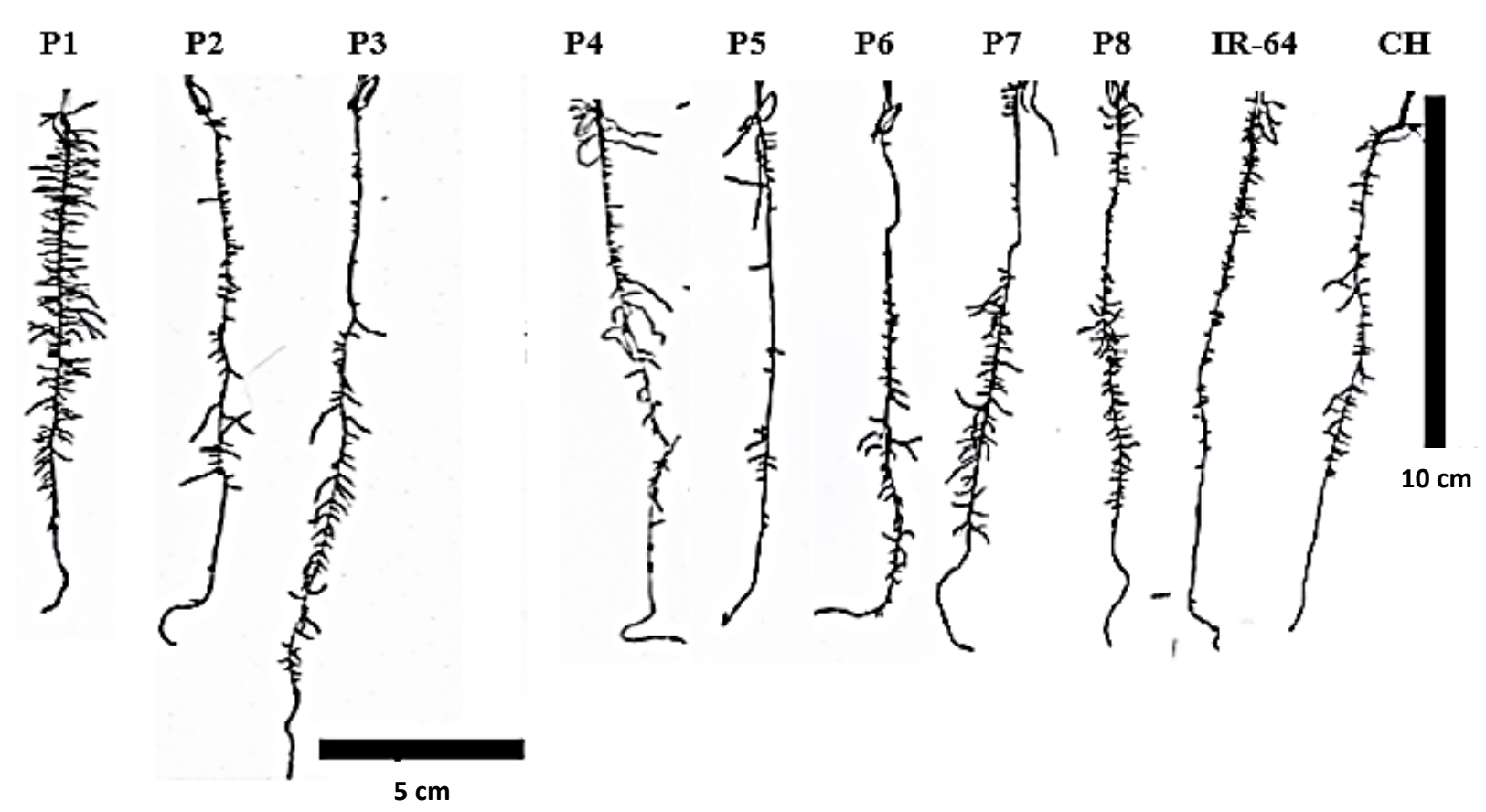

Figure 2. Root characters of ten rice cultivars aged 7 DAI (days after imbibition). P1: Pak Morin, P2: Mapan, P3: Pak Mutin, P4: Gogo Fatuhao, P5: Seratus Malam Boawae, P6: Padi Putih Kuatnana, P7: Padi Putih Maumere, P8: Gogo Sikka, IR64, CH: Ciherang 
Table 2. Morphological changes (plant height, number of leaves and number of tillers) of eight NTT local rice cultivars as affected by decreasing Field Capacities (FCs)

\begin{tabular}{|c|c|c|c|c|c|c|c|c|c|}
\hline \multirow{2}{*}{ Cultivar } & \multicolumn{3}{|c|}{ Plant height $(\mathrm{cm})$} & \multicolumn{3}{|c|}{ Leaf number } & \multicolumn{3}{|c|}{ Tiller number } \\
\hline & FC 100\% & FC 50\% & FC 25\% & FC $100 \%$ & FC 50\% & FC 25\% & FC $100 \%$ & FC 50\% & FC 25\% \\
\hline P1 & $51.50^{\mathrm{b}}$ & $54.38^{\mathrm{bc}}$ & $54.75^{\mathrm{bc}}$ & $11.75^{\mathrm{ab}}$ & $10.50^{\mathrm{ab}}$ & $9.75^{\mathrm{abc}}$ & $3.25^{\mathrm{abc}}$ & $2.00^{\mathrm{ab}}$ & $2.00^{\mathrm{abc}}$ \\
\hline $\mathrm{P} 2$ & $53.00^{\mathrm{b}}$ & $53.13^{b c}$ & $53.88^{b c}$ & 26.50 de & $16.75^{\mathrm{c}}$ & $16.25^{\mathrm{cd}}$ & $5.00^{\mathrm{c}}$ & $3.25^{\mathrm{bc}}$ & $3.25^{\mathrm{bc}}$ \\
\hline P3 & $54.13^{b}$ & $47.50^{\mathrm{b}}$ & $47.38^{\mathrm{b}}$ & $14.75^{a b c}$ & $16.00^{\mathrm{c}}$ & $13.50^{\mathrm{bcd}}$ & $2.50^{\mathrm{ab}}$ & $2.75^{a b c}$ & $3.25^{\mathrm{c}}$ \\
\hline P4 & $52.00^{\mathrm{b}}$ & $53.00^{\mathrm{bc}}$ & $53.00^{\mathrm{bc}}$ & $17.25^{\mathrm{bc}}$ & $14.25^{\mathrm{bc}}$ & $11.25^{\mathrm{abc}}$ & $3.25^{\mathrm{abc}}$ & $2.75^{\mathrm{ab}}$ & $2.25^{\mathrm{abc}}$ \\
\hline P5 & $61.63^{b c}$ & $59.88^{\mathrm{cd}}$ & $59.88^{b c}$ & $18.50^{\mathrm{bcd}}$ & $9.25^{\mathrm{ab}}$ & $9.25^{\mathrm{ab}}$ & $3.50^{a b c}$ & $1.50^{a b c}$ & $1.75^{\mathrm{ab}}$ \\
\hline P6 & $66.50^{\mathrm{c}}$ & $66.00^{d}$ & $63.50^{\mathrm{c}}$ & $13.25^{\mathrm{ab}}$ & $10.75^{\mathrm{ab}}$ & $11.00^{\mathrm{abc}}$ & $2.75^{a b c}$ & $2.25^{\mathrm{ab}}$ & $2.25^{\mathrm{abc}}$ \\
\hline P7 & $57.38^{b c}$ & $54.00^{\mathrm{bc}}$ & $60.63^{c}$ & $10.50^{\mathrm{ab}}$ & $8.75^{\mathrm{ab}}$ & $9.00^{\mathrm{ab}}$ & $2.25^{\mathrm{ab}}$ & $1.50^{\mathrm{a}}$ & $1.50^{\mathrm{a}}$ \\
\hline P8 & $57.00^{\mathrm{bc}}$ & $50.13^{\mathrm{b}}$ & $53.88^{\mathrm{bc}}$ & $22.50^{\text {cde }}$ & $17.00^{\mathrm{c}}$ & $18.75^{\mathrm{d}}$ & $3.75^{\mathrm{bc}}$ & $3.50^{\mathrm{c}}$ & $3.50^{\mathrm{c}}$ \\
\hline IR-64 & $55.25^{\mathrm{bc}}$ & $49.25^{b}$ & $50.75^{b c}$ & $28.00^{\mathrm{e}}$ & $19.75^{\mathrm{c}}$ & $18.25^{\mathrm{d}}$ & $4.00^{b c}$ & $2.50^{a b c}$ & $3.25^{\mathrm{c}}$ \\
\hline $\mathrm{CH}$ & $30.75^{a}$ & $30.50^{\mathrm{a}}$ & $28.38^{\mathrm{a}}$ & $7.25^{\mathrm{a}}$ & $7.00^{\mathrm{ab}}$ & $6.50^{\mathrm{a}}$ & $1.25^{\mathrm{a}}$ & $1.75^{\mathrm{ab}}$ & $1.00^{\mathrm{a}}$ \\
\hline
\end{tabular}

The mean value followed by the same letter in the same column of each character indicates no significant difference based on the Duncan test at the 0.05 level. FC 100\% = Control; FC 50\% = Moderate stress; and FC25\% = Severe stress. P1: Pak Morin, P2: Mapan, P3: Pak Mutin, P4: Gogo Fatuhao, P5: Seratus Malam Boawae, P6: Padi Putih Kuatnana, P7: Padi Putih Maumere, P8: Gogo Sikka, IR64, CH: Ciherang

The development of shoots and tillers in the early vegetative period is an important process that determines the number of productive tillers which not only contribute to the seed yield of a rice crop but also the ability to recover from inappropriate growth conditions (Singh et al. 2015; Lakunthod et al. 2018). Based on the data obtained, during 46 days of planting, each rice cultivar showed different responses to the 3 levels of drought stress given. Cultivars Pak Morin, Mapan, Pak Mutin, Gogo Fatuhao, Seratus-malam Boawae, Padi-putih Kuatnana, Padi-putih Maumere, and Gogo Sikka showed significant differences in plant height $(\mathrm{p}<0.005)$ under drought conditions (Table 2). Research by Usman et al. (2013) shows that an increase in the level of drought leads to a reduction in plant growth that is reflected through plant height, biomass, and seedling propagation. Due to the drought conditions, cell membranes as constituents that regulate various cellular processes experience a loss of integrity and increased permeability under drought stress conditions (Blokhina et al. 2003).

Changes in cell membrane permeability during drought also affect the growth process which includes cell division and cell elongation. Based on the data in table 2, there was a significant decrease in the number of leaves $(p<0.05)$ in Mapan, Gogo Fatuhao, Seratus-malam Boawae, and Gogo Sikka. In drought conditions, this process also caused a significant decrease in the number of tillers $(\mathrm{p}<0.05)$ in the cultivars of Pak morin, Mapan, Gogo Fatuhao, Seratusmalam Boawae, Padi-putih Kuatnana, and Padi-putih Maumere. During drought, cell turgor pressure decreases so that in addition to inhibiting cell elongation and growth expansion, it also inhibits cell enlargement more than cell division (Pandey and Shukla 2015; Jaleel et al. 2009).

\section{Physiological characteristics of plants}

Drought is the main factor that limits the process of photosynthesis through stomatal closure and restrictions on the diffusion of $\mathrm{CO}_{2}$ (carbon dioxide), reduction of photosynthetic enzyme activity and a decrease in photosystem II (PSII) efficiency. Table 3 showed that Seratus-malam Boawae cultivar, Padi-putih Kuatnana, and Padi-putih Maumere showed higher photosynthetic rates compared to other cultivars under drought stress. In drought conditions, PSII activity to provide energy in the form of ATP becomes excessive so that there is the overproduction of electrons in the electron transport chain which stimulates the formation of oxygen free radicals (ROS) (Pandey and Shukla 2015). At severe stress levels, this condition induces the degradation of polypeptide D1 which leads to inactivation of the PSII reaction center. Plants with high tolerance ability are able to maintain this compartment so that it makes the process of photosynthesis in leaves more efficient (Mishra et al. 2019).

Research by Yang et al. (2016) shows that drought decreases the photosynthesis process in rice plants through stomata regulation. In this condition, the stomata and mesophyll conductance decrease with increasing stress levels. The ability of plants to control stomatal and mesophyll conductance in drought conditions determines plant tolerance to drought (Lauteri et al. 2014). Based on the data in Table 3, cultivars with the highest stomatal conductance under drought conditions are Mapan, Pak Mutin, and Gogo Fatuhao while the smallest are Padi-Putih Maumere and Gogo Sikka.

Decreased in stomatal conductance directly affect the decrease in intercellular $\mathrm{CO}_{2}$ concentration (Table 3). This shows that limitation by stomata activity is one of the important factors that cause a decrease in the rate of photosynthesis in drought conditions which is also related to the generation of ROS in photosystem I and II (GarciaSanchez et al. 2007). Table 3 shows that cultivars with the lowest $\mathrm{CO}_{2}$ intercellular concentrations is Gogo Sikka and the highest is Seratus-Malam Boawae. The higher the concentration of intercellular $\mathrm{CO}_{2}$ is, the more efficient the Calvin reaction takes place for the production of $\mathrm{NADP}^{+}$as an electron acceptor for the photosynthetic light-reaction. 
Table 3. Physiological Changes (Intercellular $\mathrm{CO}_{2}$ Levels, Stomatal Conductance and Transpiration Rate) of eight NTT local rice cultivars as affected by decreasing Field Capacities (FCs)

\begin{tabular}{|c|c|c|c|c|c|c|c|c|c|}
\hline \multirow{2}{*}{ Cultivar } & \multicolumn{3}{|c|}{ Intercellular $\mathrm{CO}_{2}\left(\mu \mathrm{mol} \mathrm{CO}{ }_{2} \mathrm{~mol}^{-1}\right)$} & \multicolumn{3}{|c|}{ Stomatal Conductance $\left(\mathrm{mol} \mathrm{H}_{2} \mathrm{O} \mathrm{m}^{-2} \mathrm{~s}^{-1}\right)$} & \multicolumn{3}{|c|}{ Transpiration Rate $\left(\mathrm{mmol} \mathrm{H}_{2} \mathrm{Om}^{-2} \mathrm{~s}^{-1}\right)$} \\
\hline & FC $100 \%$ & FC 50\% & FC 25\% & FC 100\% & FC 50\% & FC 25\% & FC 100\% & FC 50\% & FC 25\% \\
\hline $\mathrm{P} 1$ & $9161.3^{\mathrm{d}}$ & $8406.7^{\mathrm{bc}}$ & $5975.7^{\mathrm{c}}$ & $0306^{\mathrm{cd}}$ & $0.143^{\mathrm{a}}$ & $0.078^{\mathrm{bc}}$ & $9.52^{\mathrm{a}}$ & $8.37^{\mathrm{e}}$ & $8.63^{\mathrm{f}}$ \\
\hline $\mathrm{P} 2$ & $22813.7^{\mathrm{i}}$ & $22049.0^{\mathrm{f}}$ & $18297.3^{\mathrm{f}}$ & $0.291^{\mathrm{bc}}$ & $0.155^{\mathrm{ab}}$ & $0.081^{\mathrm{c}}$ & $5.58^{\mathrm{d}}$ & $5.24^{\mathrm{b}}$ & $4.37^{\mathrm{c}}$ \\
\hline P3 & $8493.3^{c}$ & $4762.0^{\mathrm{a}}$ & $1565.3^{\mathrm{a}}$ & $0.244^{\mathrm{a}}$ & $0.182^{\mathrm{b}}$ & $0.085^{\mathrm{c}}$ & $9.28^{\mathrm{d}}$ & $8.63^{\mathrm{e}}$ & $8.81^{\mathrm{f}}$ \\
\hline $\mathrm{P} 4$ & $21109.3^{\mathrm{h}}$ & $16690.0^{\mathrm{e}}$ & $8601.0^{\mathrm{d}}$ & $0.342^{\mathrm{e}}$ & $0.141^{\mathrm{a}}$ & $0.087^{\mathrm{c}}$ & $9.74^{\mathrm{d}}$ & $5.73^{\mathrm{cd}}$ & $4.39^{c}$ \\
\hline P5 & $27110.7^{\mathrm{j}}$ & $26172.7^{\mathrm{g}}$ & $22535.3^{\mathrm{g}}$ & $0.281^{\mathrm{b}}$ & $0.161^{\mathrm{ab}}$ & $0.067^{\mathrm{abc}}$ & $7.84^{\mathrm{c}}$ & $5.79^{\mathrm{cd}}$ & $1.23^{\mathrm{a}}$ \\
\hline P6 & $18108.7^{\mathrm{g}}$ & $17345.7^{\mathrm{e}}$ & $13477.3^{\mathrm{e}}$ & $0.317^{\mathrm{d}}$ & $0.152^{\mathrm{ab}}$ & $0.075^{\mathrm{bc}}$ & $7.87^{\mathrm{c}}$ & $5.51^{\mathrm{bc}}$ & $4.92^{\mathrm{d}}$ \\
\hline P7 & $12289.3^{\mathrm{f}}$ & $11528.0^{\mathrm{d}}$ & $7649.3^{\mathrm{d}}$ & $0.292^{\mathrm{bc}}$ & $0.130^{\mathrm{a}}$ & $0.050^{\mathrm{a}}$ & $5.66^{\mathrm{a}}$ & $6.02^{\mathrm{d}}$ & $3.65^{b}$ \\
\hline P8 & $8115.7^{b}$ & $7388.0^{\mathrm{abc}}$ & $3793.3^{b}$ & $0.301^{\text {cd }}$ & $0.138^{\mathrm{a}}$ & $0.058^{\mathrm{ab}}$ & $6.34^{b}$ & $5.52^{\mathrm{bc}}$ & $5.19^{e}$ \\
\hline IR-64 & $10506.7^{\mathrm{e}}$ & $9748.7^{\mathrm{cd}}$ & $6059.3^{c}$ & $0.299^{\text {bcd }}$ & $0.131^{\mathrm{a}}$ & $0.051^{\mathrm{a}}$ & $5.63^{\mathrm{a}}$ & $6.04^{\mathrm{d}}$ & $3.66^{\mathrm{b}}$ \\
\hline $\mathrm{CH}$ & $6130.0^{\mathrm{a}}$ & $5402.0^{\mathrm{ab}}$ & $1949.3^{\mathrm{a}}$ & $0.308^{\mathrm{cd}}$ & $0.153^{\mathrm{ab}}$ & $0.050^{\mathrm{a}}$ & $5.12^{\mathrm{a}}$ & $4.82^{\mathrm{a}}$ & $3.61^{b}$ \\
\hline
\end{tabular}

Note: * The mean value followed by the same letter in the same column of each character indicates no significant difference based on the Duncan test at the 0.05 level. FC 100\% = Control; FC 50\% = Medium stress; and FC25\% = Severe stress. P1: Pak Morin, P2: Mapan, P3: Pak Mutin, P4: Gogo Fatuhao, P5: Seratus Malam Boawae, P6: Padi Putih Kuatnana, P7: Padi Putih Maumere, P8: Gogo Sikka, IR64, CH: Ciherang

The change in $\mathrm{CO}_{2}$ assimilation and stomatal conductance during the drought process significantly ( $p$ $<0.05$ ) affected the changes in the transpiration rate of NTT local rice plants. Table 3 showed that the higher the stress level (25\% of field capacity) is, the lower the transpiration rate of all rice cultivars. Recent studies indicate that food crops such as wheat, maize, and rice have significant reductions when exposed to drought conditions (Jaleel et al. 2008; Farooq et al. 2009). However, Pak Morin, Pak Mutin and Padi Putih Kuatnana cultivar show a smaller rate of decline when treated with drought. Based on research by Riaz et al. (2003), the rate of transpiration determines the level of plant tolerance. Cultivars with the ability to release less water through the stomata and store more water in plant tissues are classified as drought-tolerant plants, so based on the analysis in this study, Seratus malam-Boawae cultivar (1.23 mmol $\left.\mathrm{H}_{2} \mathrm{O} \mathrm{m}-2 \mathrm{~s}-1\right)$ and Padi Putih Maumere cultivar $\left(3.65 \mathrm{mmol} \mathrm{H}_{2} \mathrm{O} \mathrm{m}-2 \mathrm{~s}-1\right)$ has the potential to be a drought-tolerant cultivar candidate.

The efficiency of the photosynthesis process depends not only on the $\mathrm{CO}_{2}$ concentration but also on the condition of photosynthetic pigments in plants, namely chlorophyll, and carotenoids. Taiz and Zeiger (2002) revealed that photosynthetic pigments are responsible as the center of photochemical reactions in leaf tissue. Drought conditions cause changes in chlorophyll content as a result of damage to chloroplasts by regeneration of ROS during the desiccation process. This is indicated by the change in chlorophyll-a which is less affected compared to chlorophyll b under drought conditions (Riaz et al. 2013). Based on the results in Figure 3.A, there were significant decreases in total chlorophyll levels $(p<0.05)$ in NTT local rice cultivars subjected to drought stress, except for Gogo Fatuhao cultivar rice with the smallest decrease. The smaller the effect of drought on the reduction of total chlorophyll content of plants during drought, the more tolerant the photosynthesis process of a plant to drought conditions.

The same trend of decreasing carotenoid levels was observed in local NTT rice plants which were exposed to drought stress. Recent studies have shown a decrease in chlorophyll and carotenoid levels in some plant species caused by drought stress (Abbasi et al. 2014). Figure $3 \mathrm{~b}$ shows that some plants actually show an increase in carotenoid levels when subjected to drought.

Decreased levels of the two pigments that occur during this drought stress can be caused by changes in the lipid to protein ratio, and also can be caused by increase of chlorophyllase activity (Abbasi et al. 2014). In addition, the effects of drought stress tend to cause chloroplasts, as compartments for photosynthetic pigments more susceptible to excessive energy excitation leading to oxidative stress induction and inhibition of pigment synthesis in leaves (Lauteri et al. 2014).

\section{Drought stress character}

The sensitivity of each cultivar can be different in drought stress depending on the resilience character of each cultivar (Cabello et al. 2013). Some parameters that show tolerance to drought are relative water content (RWC), cell membrane stability index and proline content. In some cultivars, the level of relative water content is related to the regulation of water loss in plant tissue. In addition, during physiological changes, plants regulate it by accumulating osmotic active compounds called osmoprotectants of different types and concentrations depending on species (Taiz and Zeiger 2002).

One of the main symptoms that indicate water deficiency in plants is the relative water content which is known to decrease with increasing of water stress levels (Siddique et al. 2000). Study of physiological changes in drought-tolerant plants with regards to water status in the early vegetative phase shows that tolerant plants have high relative water content (RWC) with high cell membrane stability index (CMS) that leads to minor cell membrane damage (Abbasi et al, 2014 ). Based on the results in Table 4 , each variety has significantly different RWC and CMS ( $\mathrm{p}<0.05$ ) with cultivars Gogo Fatuhao, Seratus-Malam Boawae, and Padi putih Maumere cultivar have a high RWC supported by a large CMS. The highest sensitivity to 
water deficiency correlates with high cell membranedamage in non-tolerant plants, and vice versa (Bajji et al. 2002). This is because the stability and integrity of the membrane under drought conditions is a character that guarantees cell biochemical processes including nutrient transport, signaling, photosynthesis, and other processes that can run optimally.

Plants that were treated by drought will be induced to accumulate proline. The accumulation of proline in cells can regulate the balance of osmotic differences between the cell surroundings and the cytosolic environment (Singh et al. 2017). In the study by Ashraf and Foolad (2007), osmoprotectants are universal in regulating osmotic adjustment in cells, preventing the effects of damage by ROS, and preventing damage to membranes and metabolic enzymes. Research conducted by Shehab et al. (2010) and Usman et al. (2013); showed that osmotic adjustments made through the accumulation of proline, sucrose, glycine-betaine, and other compounds in the cytoplasm can increase the rate of water absorption from a dry environment.

Table 4 shows that in drought conditions, proline levels in the tissue was increased in each cultivar. The data shows that Mapan, Seratus-Malam Boawae, and Padi Putih
Maumere cultivar showed an increase in proline levels from $100 \%$ field capacity (control) to field capacity of $25 \%$ (severe drought) by Mapan (55.16\%); Seratus Malam Boawae (53.38\%) and Padi putih Maumere (60.17\%). Plant tolerance ability to drought is demonstrated through the ability of high proline accumulation in the tissues, so that the greater the amount of increase in proline levels, the higher the plant's tolerance to environmental water stress.

Selection of local rice cultivars that are tolerant of drought is very important for the needs of developing drought-tolerant seeds and commercial food production. Based on research that has been done, it is confirmed that an increase in the level of drought stress leads to a decrease in plant growth and development that is reflected by the character of plant height, number of leaves and number of tillers in line with previous studies (Swapna and Shylaraj 2017; Singh et al. 2017). Physiologically, drought stress results in a decrease in the rate of photosynthesis, chlorophyll and carotenoid pigment levels, as well as changes in plant transpiration rate (Riaz et al. 2013; Mishra et al. 2019). Specifically, this study examines the selection process of NTT local rice cultivars through morphophysiological responses at the beginning of the vegetative period of rice plants.
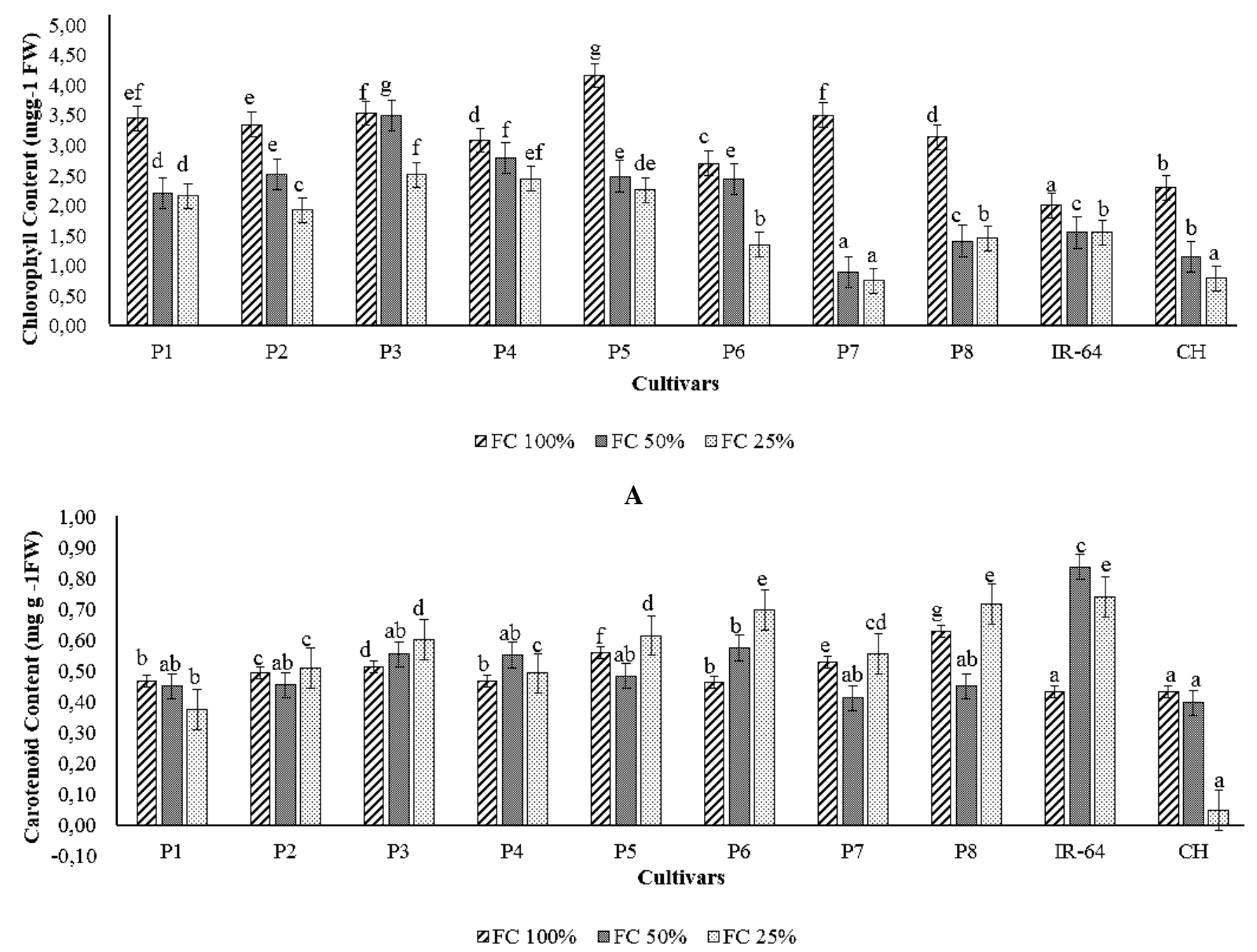

B

Figure 3. Changes in photosynthetic pigments A. Total chlorophyll and B. Carotenoid pigments in NTT local rice after drought stress vegetative stage. The same letter in the same treatment (FC) indicates no significant differences. P1: Pak Morin, P2: Mapan, P3: Pak Mutin, P4: Gogo Fatuhao, P5: Seratus Malam Boawae, P6: Padi Putih Kuatnana, P7: Padi Putih Maumere, P8: Gogo Sikka, IR64, CH: Ciherang 
Table 4. Drought stress characteristics (relative water content, membrane stability index and proline levels) of eight NTT local rice cultivars as affected by decreasing Field Capacities (FCs)

\begin{tabular}{|c|c|c|c|c|c|c|c|c|c|}
\hline \multirow{2}{*}{ Cultivar } & \multicolumn{3}{|c|}{ Relative water content $(\%)$} & \multicolumn{3}{|c|}{ Cell membrane stability index (\%) } & \multicolumn{3}{|c|}{ Proline content $\left(\mu \mathrm{mol} \mathrm{g}{ }^{-1} \mathrm{FW}\right)$} \\
\hline & FC 100\% & FC 50\% & FC 25\% & FC 100\% & FC 50\% & FC 25\% & FC 100\% & FC 50\% & FC 25\% \\
\hline P1 & $77.64^{\mathrm{abc}}$ & $58.38^{\text {bcd }}$ & $37.41^{\mathrm{cd}}$ & $86.19^{a}$ & $76.31^{\mathrm{a}}$ & $36.55^{\mathrm{ab}}$ & $0.77^{\mathrm{a}}$ & $1.10^{\mathrm{b}}$ & $1.13^{\mathrm{a}}$ \\
\hline $\mathrm{P} 2$ & $69.03^{a b c}$ & $45.62^{\mathrm{abc}}$ & $18.99^{\mathrm{abc}}$ & $86.24^{\mathrm{a}}$ & $71.98^{\mathrm{a}}$ & $54.24^{\text {ab }}$ & $1.36^{\mathrm{b}}$ & $1.36^{\mathrm{bc}}$ & $3.03^{\mathrm{c}}$ \\
\hline P3 & $67.12^{a b c}$ & $44.08^{a b c}$ & $17.63^{\mathrm{abc}}$ & $85.48^{\text {a }}$ & $67.80^{\mathrm{a}}$ & $26.93^{\mathrm{a}}$ & $0.73^{\mathrm{a}}$ & $1.20^{\mathrm{bc}}$ & $1.20^{\mathrm{a}}$ \\
\hline P4 & $75.06^{\mathrm{abc}}$ & $54.22^{\mathrm{abcd}}$ & $31.26^{\mathrm{bcd}}$ & $92.30^{\mathrm{a}}$ & $74.11^{\mathrm{a}}$ & $45.24^{\mathrm{ab}}$ & $0.62^{\mathrm{a}}$ & $0.73^{\mathrm{a}}$ & $0.92^{\mathrm{a}}$ \\
\hline P5 & $82.56^{\mathrm{abc}}$ & $62.70^{\mathrm{cd}}$ & $41.60^{\mathrm{d}}$ & $89.81^{\text {a }}$ & $80.45^{\mathrm{a}}$ & $65.81^{\mathrm{b}}$ & $0.70^{\mathrm{a}}$ & $1.35^{\mathrm{bc}}$ & $1.51^{\mathrm{b}}$ \\
\hline P6 & $86.79^{b c}$ & $68.46^{\mathrm{d}}$ & $49.37^{\mathrm{d}}$ & $90.92^{\mathrm{a}}$ & $82.46^{\mathrm{a}}$ & $37.44^{a b}$ & $0.75^{a}$ & $1.12^{\mathrm{b}}$ & $1.52^{\mathrm{b}}$ \\
\hline P7 & $89.1^{c}$ & $68.59^{d}$ & $47.49^{d}$ & $88.57^{\mathrm{a}}$ & $76.73^{\mathrm{a}}$ & $46.28^{a b}$ & $0.64^{\mathrm{a}}$ & $1.32^{b c}$ & $1.61^{\mathrm{b}}$ \\
\hline P8 & $65.69^{a b}$ & $41.31^{\mathrm{ab}}$ & $13.08^{\mathrm{ab}}$ & $88.92^{\mathrm{a}}$ & $79.98^{\text {a }}$ & $31.71^{\mathrm{ab}}$ & $1.32^{\mathrm{b}}$ & $1.54^{\mathrm{c}}$ & $1.52^{\mathrm{b}}$ \\
\hline IR-64 & $62.48^{a}$ & $37.29^{\mathrm{a}}$ & $10.98^{a}$ & $89.27^{\mathrm{a}}$ & $77.33^{\mathrm{a}}$ & $39.24^{\mathrm{ab}}$ & $0.73^{\mathrm{a}}$ & $0.73^{\mathrm{a}}$ & $0.95^{\mathrm{a}}$ \\
\hline $\mathrm{CH}$ & $76.16^{a b c}$ & $56.71^{\mathrm{abcd}}$ & $35.38^{\mathrm{cd}}$ & $90.09^{a}$ & $77.10^{\mathrm{a}}$ & $43.74^{a b}$ & $1.13^{\mathrm{a}}$ & $1.36^{\mathrm{bc}}$ & $1.56^{\mathrm{b}}$ \\
\hline
\end{tabular}

Note: Mean values followed by the same letters in the same column and row of each character do not differ significantly at the 0.05 level. FC 100\% = Control; FC 50\% = moderate stress; and 25\% = severe stress. P1: Pak Morin, P2: Mapan, P3: Pak Mutin, P4: Gogo Fatuhao, P5: Seratus Malam Boawae, P6: Padi Putih Kuatnana, P7: Padi Putih Maumere, P8: Gogo Sikka, IR64, CH: Ciherang

The tolerance of NTT local rice to drought stress evaluated during the vegetative phase has differed between cultivars. Based on the morphological, physiological and biochemical analysis, there are significant differences between control conditions (100\% field capacity) and moderate $(50 \%)$ and severe $(25 \%)$ conditions. The ability of drought tolerance was demonstrated by several cultivars on various test parameters include higher relative water content that supports a high membrane stability index (minimize damage to cell membranes). This mechanism is important to support photosynthesis and the efficiency of proline accumulation as an osmotic defense mechanism and regulating turgor pressure for cell expansion and division, and regulation of stomatal conductance. In this study, cultivars that showed the lowest values of these parameters (having a high sensitivity to water stress) were Pak mutin while cultivars that showed drought tolerance were Seratus-malam Boawae, Padi-putih Kuatnana, and Padi-putih Maumere.

\section{ACKNOWLEDGEMENTS}

Authors acknowledge the financial support provided by the Directorate of Research and Community Service, Directorate General of Research and Development Strengthening, the Ministry of Research, Technology, and Higher Education, Republic of Indonesia through PMDSU research grant (2018-2019). Authors also thanked the Faculty of Biology, Gadjah Mada University (UGM), Yogyakarta, Indonesia as the provider of the Research Station and Greenhouse as well as the Plant Physiology laboratory and joint research facilities.

\section{REFERENCES}

Abbasi AR, Sarvestani R, Nargesi BM, Baghery A. 2014. Drought stressinduced changes at physiological and biochemical levels in some common Vetch (Vicia sativa L.) genotypes. J Agric Sci Tech 16 (3): 505-516.
Ashraf M, Foolad MR. 2007. Roles of glycine betaine and proline in improving plant abiotic stress resistance. Environ Exp Bot 59: 206216.

Bajji M, Kinet JM, Luuts S. 2002. The use of the electrolyte leakage method for assessing cell membrane stability as a water stress tolerance test in durum wheat. Plant Growth Regul 36 (1): 61-70.

Bates LS, Waldran RP, Teare ID. 1973. Rapid determination of free proline for water-stress studies. Plant Soil 39: 205.

Blokhina O, Virolainen E, Fagerstedt KV. 2003. Antioxidants, oxidative damage and oxygen deprivation stress: A review. Anal Bot 91: 179194.

Bunnag S, Pongthai P. 2013. Selection of rice (Oryza sativa L.) cultivars tolerant to drought stress at the vegetative stage under field conditions. Am J Plant Sci 4 (9): 1701-1708.

Cabello JV, Lodeyro AF, Zurbriggen MD. 2013. Novel perspectives for the engineering of abiotic stress tolerance in plants. Curr Opin Biotechnol 26: 62-70.

Garcia-Sanchez F, Syvertsen JP, Gimeno V, Botia P, Perez-Perez JG. 2007. Responses to flooding and drought stress by two citrus rootstock seedlings with different water use efficiency. Physiol Plant 130: 532-542.

Guo P, Baum M, Grando S, Ceccarelli S, Bai G, Li R, von Korff M, Varshney RK, Graner A, Valkoun J. 2009. Differentially expressed genes between drought-tolerant and drought-sensitive barley genotypes in response to drought stress during the reproductive stage. J Exp Bot 60 (12): 3531-3544.

Harborne JB. 1984. Phytochemical Methods: A Guide to Modern Technique of Plant Analysis. 2nd ed. Chapman and Hall, London.

Hosang EY, Bombo Y, Basuki T. 2016. Keragaman plasma nutfah padi gogo lokal Sumba Barat Daya Provinsi Nusa Tenggara Timur. Bul Plasm Nutfah 22 (2): 93-100. [Indonesian]

Hsiao TC, Xu LK. 2000. Sensitivity of growth of roots versus leaves to water stress: biophysical analysis and relation to water transport. J Exp Bot 51 (350): 1595-616

Jaleel CA, Manivannan P, Wahid A, Farooq M, J.Al-Juburi H, Somasundaram R, Panneerselvam R. 2009. Drought stress in plants: a review on morphological characteristics and pigments composition. Intl J Agric Biol 11: 100-105.

Lakunthod P, Nounjan N, Siangliw JL, Toojinda T, Sanitchon J, Jongdee B, Theerakulpisut P. 2018. Physiological responses under drought stress of improved drought-tolerant rice lines and their parents. Notulae Botanicae Horti Agrobotanici Cluj-Napoca 46 (2): 679-687. DOI: $10.15835 / \mathrm{nbha} 46211188$

Lauteri M, Haworth M, Serraj R, Monteverdi MC, Centritto M. 2014. Photosynthetic diffusional constraints affect yield in drought stressed rice cultivars during flowering. PloS One. DOI: 10.1371/journal.pone.0117631

Lum MS, Hanafi MM, Rafii YM, Akmar ASN. 2014. Effect of drought stress on growth, proline, antioxidant enzyme activity of upland rice. J Anim Plant Sci 24 (5): 1487-1493 
Maisura MA, Chozin, Lubis I, Junaedinand A, Ehara H. 2014. Some physiological character responses of rice under drought conditions in a paddy system. J Intl Southeast Asian Agric Sci 20 (1): 104-114.

Mishra SS, Behera PK, Panda D. 2019. Genotypic variability for drough tolerance-related morpho-physiological traits among indigenous rice landraces of Jeypore tract of Odisha, India. J Crop Imp 33 (2): 254 278.

Mullan D, Pietragalla J. 2012. Leaf relative water content. In: Pask AJD, Pietragalla J, Mullan D, Reynolds M (eds) Physiological breeding II: A field guide to wheat phenotyping. CIMMYT, Mexico.

Pandey V, Shukla A. 2015. Acclimation and tolerance strategies of rice under drought stress. Rice Sci 22 (4): 147-161.

Riaz A, Younis A, Taj AR, Karim A, Tariq U, Munir S, Riaz S. 2013 Effect of drought stress on growth and flowering of marigold (Tagetes erecta L.). Pak J Bot 45: 123-131

Shehab GG, Ahmed OK, El-Beltagi HS, 2010, Effects of various chemical agents for alleviation of drought stress in rice plants (Oryza sativa L.), Not Bot Hort Agrobot Cluj 38 (1): 139-148.
Siddique MRB, Hamid A, Islam MS. 2000. Drought stress effects on water relations of wheat. Bot Bul Acad Sin 41: 35-39.

Singh B, Redddy KR, Redona ED, Walker T. 2017. Screening of rice cultivars for morpho-physiological responses to early season soil moisture stress. Rice Sci 24 (5): 322-335.

Swapna S, Shylaraj KS, 2017. Screening for osmotic stress responses in rice cultivars under drought condition. Rice Sci 24 (5): 253-263.

Taiz L, Zeiger E. 2002. Plant Physiology $2^{\text {nd }}$ ed. The Benjamin/Cummings Publisher. California.

Usman M, Raheem ZF, Ahsan T, Iqbal A, Sarfaraz ZN, Haq Z. 2013. Morphological, physiological, and biochemical attributes as indicators for drought tolerance in rice (Oryza sativa L.). Eur J Biol Sci 5 (1): 23-38.

Yang Y, Guan H, Batelaan O, McVicar TR, Long D, Piao S, Liang W, Liu B, Jin Z, Simmons CT. 2016. Contrasting responses of water use efficiency to drought across global terrestrial ecosystems. Sci Rep 6: (23284) DOI: $10.1038 /$ srep23284 